\title{
Counterfactual Romanticism
}
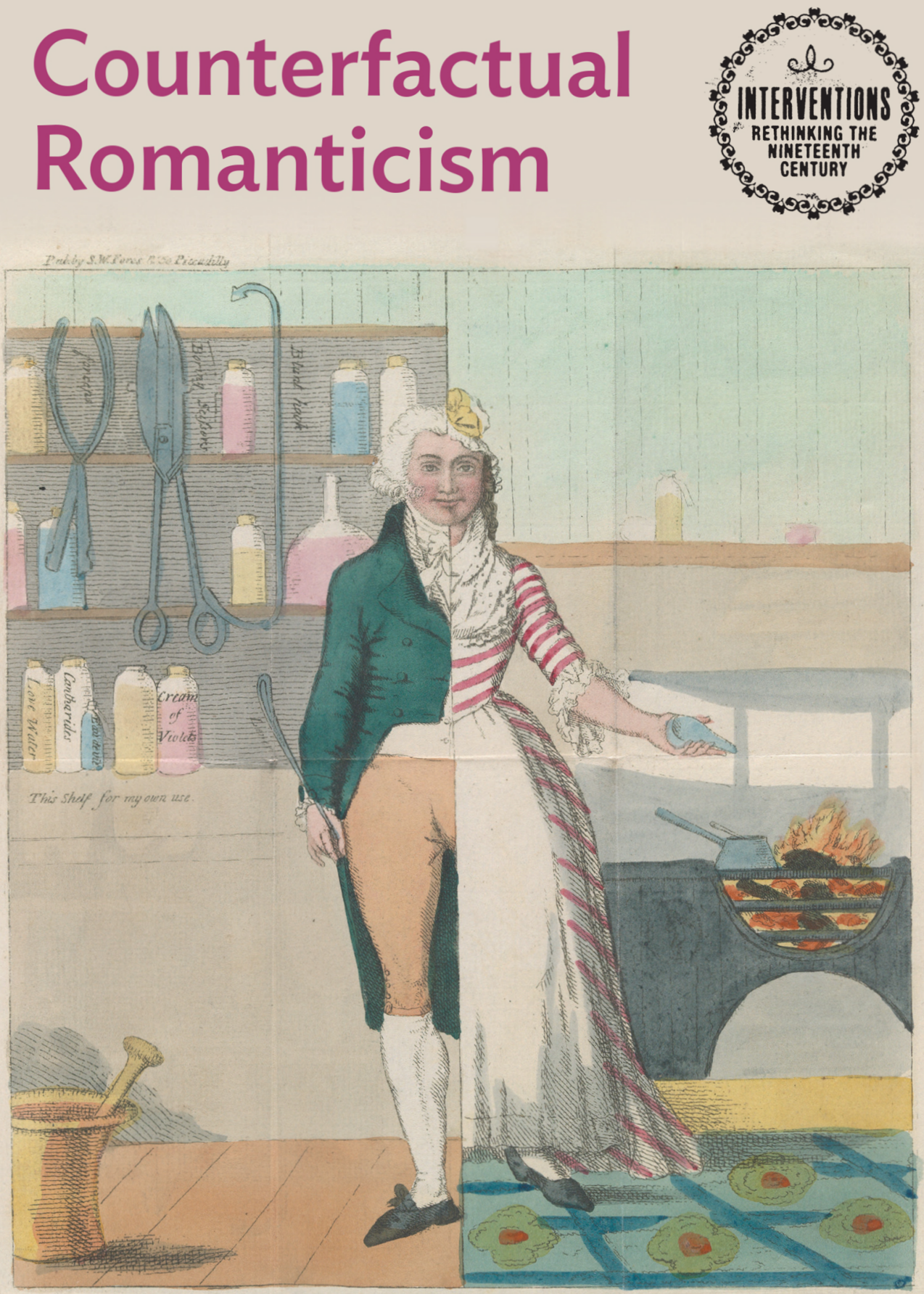

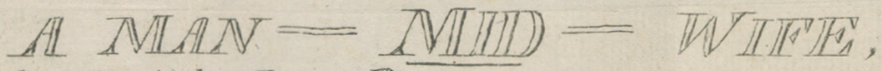

or a newly discover'd animal, not Known in Buffon's time; for a more full description of this Monster. se. an ingenious look, lately pubtish'd, price $3 / \sigma$, entilled, Man $-M$ idwifery difsected, containing a variety sf well authenticated cases, clucidating this animal's Propensities to cruclty \& indecercy, sold by the pubisher

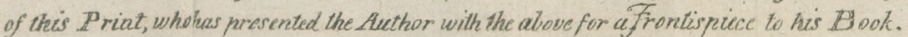




\section{Counterfactual Romanticism}

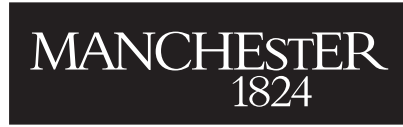

Manchester University Press 


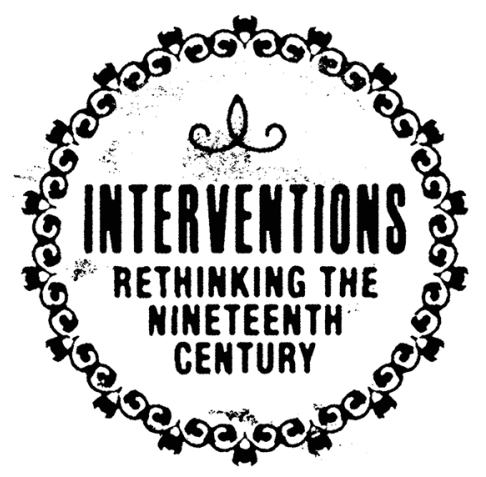

Series editors: Anna Barton, Andrew Smith

Editorial board: David Amigoni, Isobel Armstrong, Philip Holden, Jerome McGann, Joanne Wilkes, Julia M. Wright

Interventions: Rethinking the Nineteenth Century seeks to make a significant intervention into the critical narratives that dominate conventional and established understandings of nineteenth-century literature. Informed by the latest developments in criticism and theory the series provides a focus for how texts from the long nineteenth century, and more recent adaptations of them, revitalise our knowledge of and engagement with the period. It explores the radical possibilities offered by new methods, unexplored contexts and neglected authors and texts to re-map the literary-cultural landscape of the period and rigorously re-imagine its geographical and historical parameters. The series includes monographs, edited collections, and scholarly sourcebooks.

Already published

Spain in the nineteenth century: New essays on experiences of culture and society Andrew Ginger and Geraldine Lawless

Creating character: Theories of nature and nurture in Victorian sensation fiction Helena Ifill

Margaret Harkness: Writing social engagement 1880-1921 Flore Janssen and Lisa C. Robertson (eds)

Richard Marsh, popular fiction and literary culture, 1890-1915: Re-reading the fin de siècle Victoria Margree, Daniel Orrells and Minna Vuohelainen (eds)

Charlotte Brontë: Legacies and afterlives Amber K. Regis and Deborah Wynne (eds) The Great Exbibition, 1851: A sourcebook Jonathon Shears (ed.)

Interventions: Rethinking the nineteenth century Andrew Smith and Anna Barton (eds) 


\title{
Counterfactual Romanticism
}

\author{
Edited by Damian Walford Davies
}

Manchester University Press 
While copyright in the volume as a whole is vested in Manchester University Press, copyright in individual chapters belongs to their respective authors, and no chapter may be reproduced wholly or in part without the express permission in writing of both author and publisher.

Published by Manchester University Press

Altrincham Street, Manchester M1 7JA

www.manchesteruniversitypress.co.uk

British Library Cataloguing-in-Publication Data

A catalogue record for this book is available from the British Library

ISBN 9781784991418 hardback

First published 2019

The publisher has no responsibility for the persistence or accuracy of URLs for any external or third-party internet websites referred to in this book, and does not guarantee that any content on such websites is, or will remain, accurate or appropriate.

Cover image: 'Man-midwifery dissected...' by Samuel William Fores, 1795. Courtesy of the Wellcome Foundation (CC BY)

Typeset in 10/12 Adobe Caslon Pro by

Servis Filmsetting Ltd, Stockport, Cheshire 